\title{
Risk management of European inland waters using macrophyte biomonitoring
}

\section{David Delmail *}

CNRS UMR 6226 ISCR (Institute of Chemical Sciences of Rennes), University of Rennes 1, European University of Brittany, Rennes, France

\section{Edited by:}

Aziz Ullah, Kohat University of

Science and Technology, Pakistan

Reviewed by:

Rajeshwar P. Sinha, Banaras Hindu

University, India

Peter Rolf Richter,

Friedrich-Alexander-University,

Germany

\section{*Correspondence:}

David Delmail, CNRS UMR 6226

ISCR (Institute of Chemical Sciences

of Rennes), University of Rennes 1,

2 Ave. Prof. Léon Bernard, F-35043

Rennes Cedex, France

e-mail: david.delmail@

univ-rennes 1.fr
Inland waters are extremely sensitive to inputs of contaminants. Increasing human activities lead to a rise in organic and inorganic pollutants leading to acidification or eutrophication problems. Many aquatic organisms are affected by these contaminants and significant modifications of their community composition have been recorded. As part of the European Water Framework Directive, macrophyte biomonitoring has been developed to assess the quality of waters and their ecological status. The purpose of such studies was to establish the macrophyte-community composition as an indicator of the pollution level using multivariate approaches. As the various macrophyte indices evolve in concordance with European environmental policy needs, spatial and temporal comparisons between aquatic environments from different regions or countries would be possible.

Keywords: inland waters, European water framework directive, xenobiotics, macrophyte, biomonitoring

\section{INTRODUCTION}

Inland-water pollution is a problem worldwide. As a result of industrial development, demographic growth and intensification of agriculture, this phenomenon has reached an alarming level. It induces a loss of its overall quality which disrupts from any natural or regular use due to human-health dangerousness and aquatic-ecosystem disturbance. It can concern groundwaters, lakes, rivers, swamps, and wetlands. Water contamination has many origins including agrochemicals (fertilizers and pesticides), industrial by-products and untreated sewages (Miquel, 2003).

Waters can dissolve most of minerals and organic chemicals as well as transporting in suspension insoluble compounds and solid wastes. All contaminants are carried far from their point of discharge through the surface waters as well as groundwaters. The consequences of aquatic pollutions can be ecological (disturbances of biological structure and function), sanitary (impact on the public health by pathogen contact) and esthetic (Delmail, 2011).

\section{EN ROUTE TO THE "GOOD STATE"}

The European Water Framework Directive (WFD) was established in 2000 to improve and to maintain the overall environmental quality of inland waters located in the European Union. It commits the member states to achieve a "good status of all water bodies" (including sea/ocean up to one nautical mile from shore) by 2015 (Fontaine and Glavany, 2000). In its second article, the WFD requests chemical and ecological water status both of good quality according to several criteria: biological, hydromorphological and chemical (physico-chemistry and xenobiotics). To reach a "good status," discharges cannot exceed the maximum authorized emission limit values and environmental quality standards established for 12 priority-substance families (CEPC, 2012).
To assess the ecological status, biomonitoring is favored. Biomonitoring is the use of organisms sensitive to a specific pollutant with a presence and/or a physiological state, related to the ecological quality (biological, chemical, functional, and microclimatic) of the environment (Tachet, 2006). It is mainly based on the diversity and the state of animals (benthic invertebrates, ichthyofauna), microorganisms (phytoplankton), and plants (macrophytes, phytobenthos).

\section{WATER-QUALITY ASSESSMENT}

The notion of inland-water quality has evolved during the three last decades with the rise of protocols to monitor water pollution. This evolution is related to knowledge updates, immediate needs in environmental monitoring and water quality. Since the 90's, the ecology of aquatic environments has been an important topic in European politics (Delmail, 2011). With the WFD, the concept of water quality has changed: a good biological state implies now a healthy state. The evaluation of the chemical state provides complementary information to support the biological state and is not the sole source of data to assess the environmental state (Steyaert and Ollivier, 2007; Chauvin et al., 2008).

We currently need methods to evaluate the health of livingorganism groups. The old protocols must be optimized to provide a solution in concordance with the environmental-health requests like discharge limits. Among aquatic organisms, research has focused on using macrophytes as bioindicators. Previous methods based on these plants need to be updated considering the new European laws and to be standardized for more effective environmental management (Chauvin et al., 2008).

\section{MACROPHYTES}

Aquatic organisms considered as "macrophytes" are photosynthetic ones with a size (or with a colony) visible to the naked 
eye. They include submerged, floating or emergent phanerogams, bryophytes, microalgae with filamentous, thallus or globular colonies, macroalgae (Characeae), pteridophytes, and to a lesser extent lichens and fungal/bacterial colonies (Chauvin et al., 2008).

Another question is where are macrophytes found? The most evident answer is where water is present for some time. So confusion can appear between macrophyte environments and wetlands as defined by the intergovernmental Ramsar Convention in 1971. Indeed this is consistent with the features of wetlands: hygrophilous plants adapted to floods or groundwaters near the surface live temporarily in these environments where superficial waters could be 6 meters at the deepest (euphotic zone) (Haury et al., 2008).

Macrophytes play an important physicochemical role, improve water clarity through sediment stabilization and act as ecosystem engineers. They are substrate for epiphyton, have a key position in trophic web and are critical habitats for invertebrates and fishes (Haury et al., 2008; Delmail, 2011).

\section{FROM CONVENTIONAL WATER QUALITY STUDIES TO INNOVATIVE BIOMONITORING}

Until the end of the 80's, monitoring using more or less sensitive and effective analytical methods (e.g., chromatography, electrochemistry) led to qualitative and quantitative identification of chemicals considered as harmful and/or toxic to inland waters and their living organisms (Delmail, 2011). Despite the need for such protocols to assess contaminant concentrations, there are limitations with chemical analyses related to sampling problems, inadequate detection limits, and costs associated with daily/weekly analyses. Moreover, some contaminants are never considered in these environmental-monitoring investigations as their behavior in surface waters is unknown, or they are new anthropogenic compounds released in nature (Ganzleben and Hansen, 2012). Although conventional chemical analyses provide details on the occurrence of certain xenobiotics and their related concentrations, they cannot highlight the pollutant impact on its final target, the living organisms.

To assess more directly environmental health, biomonitoring was proposed to complement the chemical analyses. This approach uses organisms (isolated individuals, populations, communities) at all organization levels (biochemical, cell, histology, molecular, morphology, and physiology) to anticipate or highlight an environmental perturbation and to follow environmental change (Garrec and Van Haluwyn, 2002). The biological effects of xenobiotics are thus integrated as indicators/markers to track xenobiotics/pollutions. Biomonitoring can also provide an early detection of pollution before the biocoenosis disruption, and especially before effects occur at the whole ecosystem level.

Previous methods based on macrophyte biomonitoring are now required to match with the WFD. The WFD deadlines do not allow the development of new scientific approaches which implies adapting older ones. This upgrade must also consider eventual further modifications and validations, depending on the evolving knowledge. The environmental monitoring will have to integrate constantly updates depending on what is requested to perform efficiently the inland-water management. The challenge is to develop in the next years new monitoring methodologies including the capacity to standardize with the changes in environmental legislation. Standardization will allow inter-comparisons of results from diverse geographical origins. Unfortunately environmental managers will only retain methodologies matching with laws rather than their scientific relevance (Chauvin et al., 2008).

\section{CHEMICAL PERTURBATIONS AND MACROPHYTE RESPONSES}

Environmental perturbations can refer to either relative or absolute changes in: the relative one refers to a deviation from normal ecosystem dynamics and the absolute one is based on measurable changes in chemicals. In the first one, events like annual flooding and eutrophication are not considered as perturbations, but rather as stress, due to natural occurrence (e.g., wet season) and regular occurrence (e.g., continuous nutrient release from sewage plants), respectively. However, in the second one, these events induce deviation from normal dynamics and are defined as perturbations due to, e.g., substrate erosion and loss of available dioxygen, respectively (White and Jentsch, 2001; Trémolières et al., 2008). Consequently studies in aquatic ecotoxicology are mainly focused on perturbations. A perturbation integrates the cause and consequence of an event occurring at different time and space scales which disrupt the hydrosystem structure and the organization of biological communities (Trémolières et al., 2008).

Attached hydrophytes integrate environmental disruptions and develop adaptative mechanisms. The main visible consequences are changes in (i) the abundance (e.g., Haury et al., 2006), (ii) the composition (e.g., Thiébaut and Muller, 1999), and (iii) the phytocoenosis richness (e.g., Hinojosa-Garro et al., 2008). Many phytosociological studies have underlined relationships between nutrient levels and phytocoenosis distributions (Hinojosa-Garro et al., 2008). Various indices are based on macrophyte communities and their responses toward a few kinds of pollution, e.g., acidification, eutrophication and heavy metals; they constitute a reference in water-quality categories defined by their lithological and chemical characteristics, in specific physical contexts (Trémolières et al., 2008; Delmail, 2011; Delmail and Labrousse, 2014).

\section{MACROPHYTE BIOMONITORING}

To assess the overall environmental quality of hydrosystems, most macrophyte biomonitoring methods were based on indices rather than biomarkers. Using such global and taxonomic indices, some scores were attributed to species according to their relevance in acidification (Tremp and Kohler, 1995; Thiébaut and Muller, 1999), organic pollution (Husák et al., 1989) or trophy level (Schneider, 2000; Haury et al., 2006).

Prygiel and Haury (2006) reported the Bryophyte Index of Heavy-Metal Toxiphobia (Empain et al., 1980) as one of the first indices based on aquatic macrophytes. It determines any variations consequent to heavy-metal pollution in bryophyte communities. Its use in Northern Europe predates the development of research on bioaccumulation. Phytoremediation is an important research field full of promise for the recycling of rare metals extracted from plant tissues. However, other ecotoxicological indices are still actively employed in Europe, mainly focused 
on the evident relations between macrophyte abundance and phosphate and ammonium concentrations in inland waters.

Changes in European macrophyte diversity induced by eutrophication were firstly studied using multivariate statistical methods (e.g., Monschau-Dudenhausen, 1982). Consequently, several ways of assessing the aquatic trophic state via macrophytes were developed as these plants respond differently to trophic levels depending on their geographical distribution: the British "Mean Trophic Rank" (MTR) index (Holmes, 1995), the German “Trophic Index of Macrophytes" (TIM) (Schneider, 2000) and the French "Macrophyte Biological Index for Rivers" (IBMR) (Haury et al., 2006) calculated on species scores, coefficients of ecological valence and degree of cover. Index calculations include the species abundance and the relation between species occurrence and environmental nitrogen/phosphorus concentrations as the availability of these macroelements plays an important role in controlling macrophyte distributions (Figure 1). However, the role of the macronutrient potassium is poorly known despite its high concentration as a contaminant of domestic wastewaters (Saidin et al., 2014), and its physiological importance in macrophytes (Delmail, 2011). Further investigations need to be conducted to consider its inclusion in indices. Moreover, differences occur between the species lists considered in each metrics depending on the taxon geographical optimum, e.g., mainly lowlands in MTR, supplementation of mountain affinities in IBMR and mediterranean affinities in TIM.

The United Kingdom Environment Agency has commissioned the development of the MTR scheme (Holmes et al., 1999) as a biomonitoring tool to aid in the implementation and monitoring of the European Union Urban Waste Water Treatment Directive (Dawson et al., 1999). Applications of the MTR in Poland have been attempted (Szoszkiewicz et al., 2006) and also tested within the STAR project (and in France, in comparison with the IBMR index) (Prygiel and Haury, 2006). Indeed, the European Committee for Standardization has developed the STAR program to consider and to test a standard methodology for the surveying of macrophytes throughout Europe. The STAR survey will improve existing knowledge on the ecology of river plants at a pan-European scale. This macrophyte survey is based in the detail on the field sampling procedure of the MTR. STAR has attempted to integrate the standard field techniques from previous developed indices to allow a standard system on one type of field recording from which includes the individual range of parameters. Analysis will then allow links or access to existing data collected by each country's method (Dawson, 2002). The standardized botanical surveys provide a temporal synchrony across a wide geographical area. It includes many stream types and extensive amount of environmental information. In current attempts to establish standards, correlations are first examined between macrophyte communities and trophic gradients across Europe to study the relationships between several ecological (macrophyte and global) metrics and nutrient status. Then, the development of a pan-European MTR index is attempted by the addition of further scoring species and by the rescoring of existing species (Szoszkiewicz et al., 2006). Szoszkiewicz et al. (2006) conclude that an enlarged core group of macrophyte species can form part of an improved pan-European macrophyte-based bioassessment

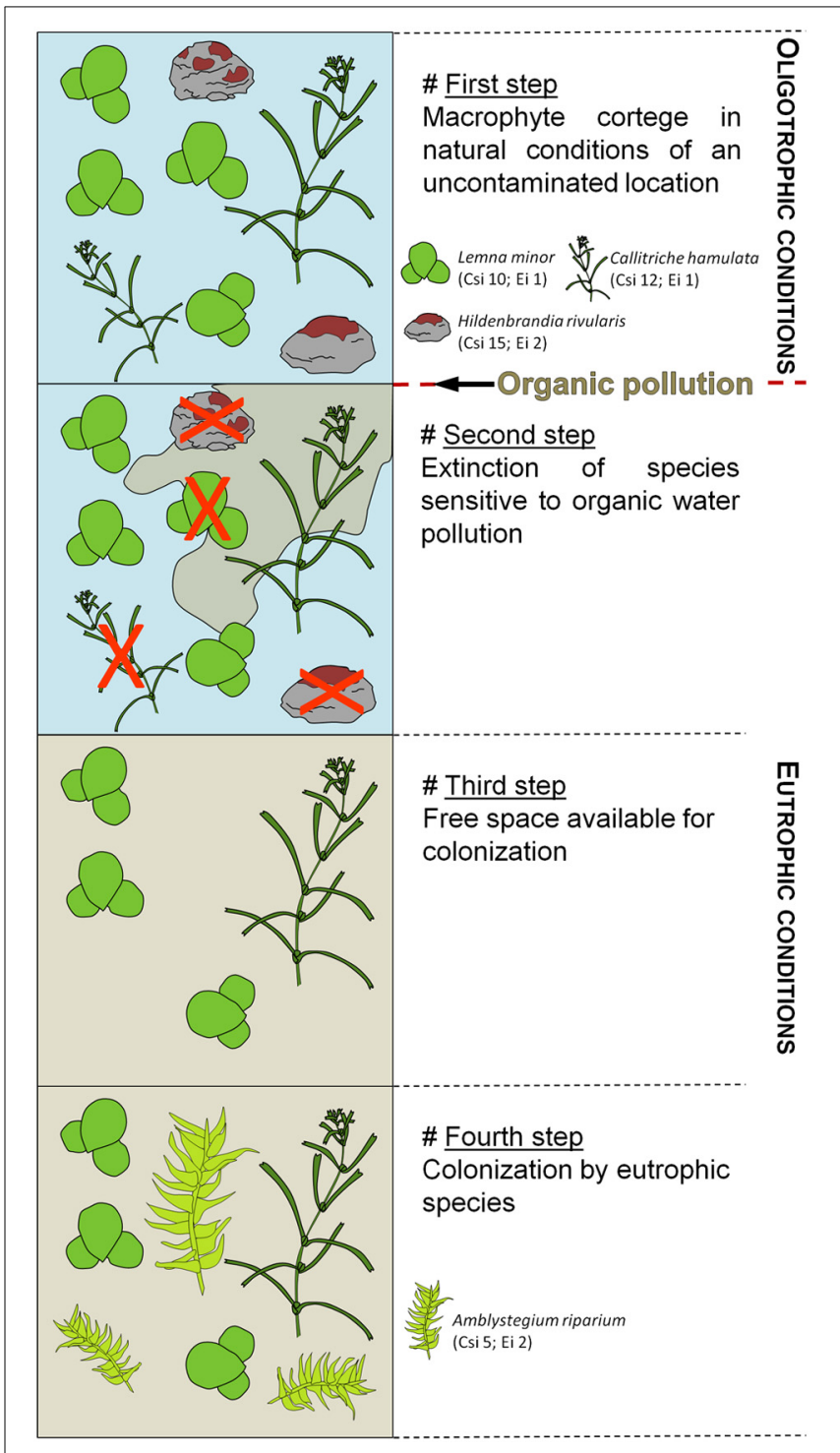

FIGURE 1 | Example of macrophyte-community dynamics in the case of eutrophication. The species presented here and their relative parameters are used in the IBMR calculation. Csi, specific trophic size (from 0 to 20); Ei, eury-stenoecie coefficient (from 1 to 3 ).

system, although regional modifications are required to efficiently describe the nutrient status of specific stream types.

More recently, research emphasis has been placed on the predictive ability, sensitivity and specificity of hydrophyte biomarkers as biomonitoring agents for environmental risk assessment. This allows the monitoring of new organic pollutions: for example, with Lemna minor Cedergreen et al. (2007) highlighted reduction of both chlorophyll and carotenoid contents and $\mathrm{EC}_{50}$ specific to a herbicide family. Chelation capabilities of pollutants are also investigated as an indicator of the contamination level. As an example, depending on hydrophyte species, the bioconcentration factor of a xenobiotic from vacuoles can be correlated to its environmental rate. This index can be of interest to study rising pollution as the hydrophyte will highly concentrate the 
contaminant and allows the early detection of pollution (Delmail et al., 2013).

In conclusion, field inventories require strong efforts to standardize protocols to be consistent with environmental legislation and to develop new methods dedicated to particular aquatic environments like artificial lakes.

\section{REFERENCES}

Cedergreen, N., Abbaspoor, M., Sørensen, H., and Streibig, J. C. (2007). Is mixture toxicity measured on a biomarker indicative of what happens on a population level? A study with lemna minor. Ecotoxicol. Environ. Saf. 67, 323-332. doi: 10.1016/j.ecoenv.2006.12.006

CEPC. (2012). River Basin Management Plans. Report on the Implementation of the Water Framework Directive (2000/60/EC). Brussels: European Commission.

Chauvin, C., Peltre, M. C., and Haury, J. (2008). La bio-indication et les indices macrophytiques, outils d'évaluation et de diagnostic de la qualité des cours d'eau. Ingénieries EAT 91-108. (special issue).

Dawson, F. H. (2002). Guidance for the Field Assessment of Macrophytes of Rivers Within the STAR Project. Dorchester: NERC-CEH Dorset.

Dawson, F. H., Newman, J. R., Gravelle, M. J., Rouen, K. J., and Henville, P. (1999). Assessment of the Trophic Status of Rivers Using Macrophytes: Evaluation of the Mean Trophic Rank - R\&D Technical Report E38. Bristol: Environment Agency.

Delmail, D. (2011). Contribution de Myriophyllum alterniflorum et de Son Périphyton à la Biosurveillance de la Qualité des Eaux Face aux Métaux Lourds. Limoges: Limoges University.

Delmail, D., and Labrousse, P. (2014). "Heavy-metal attack on freshwater side: physiological defense strategies of macrophytes and ecotoxicological ops," in Physiological Mechanisms and Adaptation Strategies in Plants Under Changing Environment, Vol. 2, eds P. Ahmad and M. Rafiq Wani (Berlin: Springer), 31-54. doi: 10.1007/978-1-4614-8600-8_2

Delmail, D., Labrousse, P., Hourdin, P., Larcher, L., Moesch, C., and Botineau, M. (2013). Micropropagation of Myriophyllum alterniflorum (Haloragaceae) for stream rehabilitation: first in vitro culture and reintroduction assays of a heavy-metal hyperaccumulator immersed macrophyte. Int. J. Phytoremed. 15, 647-662. doi: 10.1080/15226514.2012.723068

Empain, A., Lambinon, J., Mouvet, C., and Kirchamann, R. (1980). "Utilisation des bryophytes aquatiques et subaquatiques comme indicateurs biologiques de la qualité des eaux courantes," in La Pollution des Eaux Continentales-Incidences sur les Biocénoses Aquatiques, ed P. Pesson (Paris: Gauthier-Villars), 195-223.

Fontaine, N., and Glavany, J. (2000). Directive 2000/60/EC of the European Parliament and of the Council of 23 October 2000. Official Journal of the European Communities. Luxembourg: European Commission.

Ganzleben, C., and Hansen, S. F. (2012). Nanomaterials as priority substances under the water framework directive. Elni Rev. 2, 38-45.

Garrec, J. P., and Van Haluwyn, C. (2002). Biosurveillance Végétale de la Qualité de l'air. Paris: Tec. \& Doc. Lavoisier Press.

Haury, J., Dutartre, A., and Peltre, M. C. (2008). Introduction. Ingénieries EAT 3-5. (special issue).

Haury, J., Peltre, M. C., Trémolières, M., Barbe, J., Thiébaut, G., Bernez, I., et al. (2006). "A new method to assess water trophy and organic pollution: the Macrophyte Biological Index for Rivers (IBMR): its application to different types of river and pollution," in Macrophytes in Aquatic Ecosystems: From Biology to Management, eds J. M. Caffrey, A. Dutartre, J. Haury, K. J. Murphy, and P. M. Wade (Dordrecht: Springer), 153-158. doi: 10.1007/978-1-4020-5390-0_22

Hinojosa-Garro, D., Mason, C. F., and Underwood, G. J. C. (2008). Macrophyte assemblages in ditches of coastal marshes in relation to land-use, salinity and water quality. Fund. Appl. Limnol. 172, 325-337. doi: 10.1127/18639135/2008/0172-0325

Holmes, N. T. H. (1995). Macrophytes for Water and Other River Quality Assessments. Peterborough: National Rivers Authority.
Holmes, N. T. H., Newman, J. R., Chadd, S., Rouen, K. J., Saint, L., and Dawson, F. H. (1999). Mean Trophic Rank: A User's Manual - RéD Technical Report E38. Bristol: Environment Agency.

Husák, Š., Sládeček, V., and Sládečková, A. (1989). Freshwater macrophytes as indicators of organic pollution. Acta Hydrochim. Hydrobiol. 17, 693-697. doi: 10.1002/aheh.19890170612

Miquel, G. (2003). La Qualité de l'Eau et l'Assainissement en France. Paris: OPECST. Monschau-Dudenhausen, K. (1982). Wasserpflanzen als Belastungsindikatoren in Fließgewässern Dargestellt am Beispiel der Schwarzwaldflüsse Nagold und Alb. Karlsruhe: Beih. Veröff. Natursch.

Prygiel, J., and Haury, J. (2006). "Monitoring methods based on algae and macrophytes," in Biological Monitoring of Rivers: Applications and Perspectives, eds G. Ziglio, M. Siligardi, and G. Flaim (Chichester: John Wiley \& Sons), 156-170. doi: $10.1002 / 0470863781 . c h 9$

Saidin, Z. H., Tajuddin, R. M., Kamarun, D., and Rahman, N. A. (2014). "Performance of aquatic macrophytes on removal and accumulation of sulfate and potassium from domestic wastewater," in Proceedings of the International Civil and Infrastructure Engineering Conference 2013, eds R. Hassan, M. Yusoff, Z. Ismail, N. M. Amin, and M. A. Fadzil (Singapore: Springer), 769-781. doi: 10.1007/978-981-4585-02-6_66

Schneider, S. (2000). Entwicklung eines Makrophytenindex zur Trophieindikation in Fließgewässern. Aachen: Shaker Verlag.

Steyaert, P., and Ollivier, G. (2007). The European Water Framework Directive: how ecological assumptions frame technical and social change. Ecol. Soc. 12:25.

Szoszkiewicz, K., Ferreira, T., Korte, T., Baattrup-Pedersen, A., Davy-Bowker, J., and O'Hare, M. (2006). European river plant communities: the importance of organic pollution and the usefulness of existing macrophyte metrics. Hydrobiologia 566, 211-234. doi: 10.1007/978-1-4020-54 93-8_15

Tachet, H. (2006). Invertébrés d'Eau Douce - Systématique, Biologie, Écologie. Paris: CNRS Press.

Thiébaut, G., and Muller, S. (1999). A macrophyte communities sequence as an indicator of eutrophication and acidification levels in weakly mineralised streams in North-Eastern France. Hydrobiologia 410, 17-24. doi: 10.1023/A:1003829921752

Trémolières, M., Combroux, I., Thiébaut, G., and Haury, J. (2008). Réponses des communautés végétales aux conditions environnementales: perturbations ou contraintes. Ingénieries EAT 63-77. (special issue).

Tremp, H., and Kohler, A. (1995). The usefullness of macrophyte monitoring systems, examplified on eutrophication and acidification of running water. Acta Bot. Gal. 142, 541-550. doi: 10.1080/12538078.1995. 10515277

White, P. S., and Jentsch, A. (2001). "The search for generality in studies of disturbance and ecosystem dynamics," in Progress in Botany, Vol. 62, eds K. Esser, U. Luettge, J. W. Kadereit, and W. Beyschlag (Berlin: Springer), 399-450. doi: $10.1007 / 978-3-642-56849-7 \_17$

Conflict of Interest Statement: The author declares that the research was conducted in the absence of any commercial or financial relationships that could be construed as a potential conflict of interest.

Received: 03 February 2014; accepted: 25 June 2014; published online: 17 July 2014 Citation: Delmail D (2014) Risk management of European inland waters using macrophyte biomonitoring. Front. Environ. Sci. 2:31. doi: 10.3389/fenvs.2014.00031 This article was submitted to Environmental Toxicology, a section of the journal Frontiers in Environmental Science.

Copyright $(\odot 2014$ Delmail. This is an open-access article distributed under the terms of the Creative Commons Attribution License (CC BY). The use, distribution or reproduction in other forums is permitted, provided the original author $(s)$ or licensor are credited and that the original publication in this journal is cited, in accordance with accepted academic practice. No use, distribution or reproduction is permitted which does not comply with these terms. 